\title{
Criteria of Social-Ethics and Its Effects on Electronic Promotion Activities in Jordanian Higher Education
}

\author{
Mahmud Agel Abu Dalbouh ${ }^{1}$ \\ ${ }^{1}$ Department of Marketing, Irbid National University, Jordan \\ Correspondence: Mahmud Agel Abu Dalbouh, Head Department of Marketing, Irbid National University, Jordan. \\ E-mail: M_agel_dlb@yahoo.com
}

Received: June 23, 2019 Accepted: July 20, 2019 Online Published: August 19, 2019

doi:10.5539/ijms.v11n3p116 URL: https://doi.org/10.5539/ijms.v11n3p116

\begin{abstract}
The purpose of this paper is to investigate the effect of the social-ethics required criteria on electronic promotion activities for higher education in Jordan for last 20 years. More specifically, the study chose the Jordanian higher education sector (JHES). In terms of the methodology of study, the population included (100) managers of universities in Jordan but we choose (90) managers and response rate was (88) managers (98\%). The study concluded and explains that electronic promotion activities in private and public sector face a lack of rely criteria dimensions ethically, socially, rapid changes in business environment, competitors, distinctive, customer's requirements, digital revolution, target market, laws, and economy statue education requirements. The study recommended that Jordanian private higher education sector must be commitment and opt-out by their criteria dimensions in social-ethics parts by electronic promotion activities, competitive situation, develop the methods technological, enhance market share, satisfy the customers, make a marketing research, develop new methods for education sectors and the universities goals of electronic promotion.
\end{abstract}

Keywords: higher education, Jordan, social-ethics criteria, electronic promotion, managers, digital revolution

\section{Introduction}

Depend on growth of marketing importance and its branches as E-marketing, E-communication-business, it entered all aspects economic, social, cultural, dynamic environment, digital revolution (DR) which effect directly or indirectly forms on marketing activities (Mahmud Abu Dalbouh, 2019). The market imposes rigid conditions on production, customers, purchasing power, government attitudes, market orientation, and firm's visions, goals (Teas \& Agar Wales, 2000). The managers in higher education sector deal with management functions by new strategies to adaptation with a suit degree of electronic promotion with ethic, social criteria for performance to marketing those activities smoothly, fit, accurate, to achieve customers satisfaction and firms goals (Zeithmal, 2003). Customers exhibit varies behaviors for taking services and products, thus the services industry in higher education sector call for distinct marketing approaches, services are intangibility, perish ability, simultaneous production, heterogeneity and varies of judgment (Kittler, 2011). The higher education sector in Jordanian face varies customers tempers, high degree of culture, perceived values, awareness, education is valuable in social aspect, and investment (Al-dmour, 2004) in general the customers stimuli thinking of that expensive services have high quality, finally it mean the private education sector should be meet the social-ethics responsibilities to satisfy the customer preferences (Calya, Julien, \& Eric Amould, 2008). The objectives of this study are for knowledge: the impact of social-ethics on E-promotion in higher education sector, impact E-promotion mix on customer satisfaction, extent of social-ethics application and their criteria.

\section{Statement of Problems}

The importance of study is to determine according the following (Homas, 2006), managers ought to make marketing audit for goals annually at least and evaluate strategies, policies, plans, but the Jordanian higher education sector face many obstacles as: Business environment need to complete and integration for social-ethics, there are, a accelerated technological change. Increasing improves marketing activities, lack of social correlation awearance shortage of ethics criteria applications for customer satisfaction, weakness of marketing performance, education marketing mix, and electronic promotion (Kuksov, 2013), new knowledge of digital promotion, small market shares, sales, and revenues, there are objectives of study determined according to the many aspects: Emphasize on the necessity of criteria social and ethics system in electronic business environment, new 
technology, marketing methods, and e-promotion mix, Focus on the importance of correlation between social, ethics criteria and E-promotion mix for education sector to survive and grow (SG). The higher education sector in Jordan face many obstacles depend on digital environment, communication changes, differ of products and firms, high degree of competition, high supply, low demand, international standers, customer care, social responsibilities, ethics system, interaction between social responsibilities and marketing activities in higher private education sector, low degree of performance, customer perceived values, technology changes and electronic promotion mix (Jordanian higher education ministry report, 2013).

\section{Background}

The marketing activities need process of continuous progressing of harmony with the forces of the total, partial dynamic environment, interacting with rapid changes of endowers' attitude and how to increase the ability of organization performance to building branding name and positioning for achieving their goals and its details (Joung \& Demetris, 2006). The market orientation represents a main level of developing the market awareness, the business organization have achieved a high level of profitability since the market orientation has adopted a philosophy in marketing depend on rearrangement of interests and aspiration of customer. Business organizations build their strategies in market orientation depend on their responsibilities (social-ethic) by application their values on performance of marketing activities in private Jordanian higher education accordingly managers view point, and focus on developing the capabilities of managers in planning, learning, interacting, word of mouth (Hennig-thurau, 2004), these responsibilities in going on performance. Alex Garrett et al. (2017) digital chenille's for building collaborative consumption communities, the purpose of study to knowledge the effects of collaborative consumption firms leverage networked peers, communicating, collaborating and even delivering services for another through central marketplace channel, the study findings identifies the digital channel, typology of each of 30 firms associated, it shows distinct increase in the use of social-ethics and community digital channels.

Samreen Lodhi and Maria shoaib (2017) impact of e-marketing orientation on consumer behavior, a case of Karachi, Pakistan "the study exploring the statue of increasing technologies in the business world marketers job changes from billboard and print advertisement to more one e-marketing mediums, today companies focused on designing the web-page for marketing their product rather than showing advertisements on TV, billboard, magazines, newspapers, this research showed that almost $80-98 \%$ people are attracted with the online advertisements which is done mostly on social websites, it focus and recommend that companies should adopt e-marketing, e-buying and e-selling online banking facilities with ethics and social regulations. Fatema Haji Habibi et al. (2015) "E-marketing orientation and social media implementation in b2b marketing", the study exploring the substantive contribution to $\mathrm{b} 2 \mathrm{~b}$ marketing practice by identifying actions that managers can undertake to deal with major issues as ethics-social and others that are reported by practitioners, structural, job design changes required, and focus on and recommend highlight how these need to be used successful choices in terms of appropriate social media platforms and message execution.

Alsamak Mohammad (2014) "the ethic regulation for media" Syria. The study aimed to knowledge the basic jurisprudence in Islam religion as ethic, responsibility, accounting and explain how the Islam focus on ethics fundamentals, accounting and commitment it recommended to audit, check, validity, integrity, equity, justice. The study aimed to the importance of many rules as knowledge, behavior, decision marketing abilities, and explains the necessity of data bias in public and private sectors. It recommended to necessity of update data continuously, but rules to accountability firms, focus on quality and commitment it, motivate employee to act by socially-ethically way. Abd Alhady Ahmad (2014) "The managerial ethics and social responsibilities of firms", Jordan. The study aimed to define the rules of ethical-social acts for employee behavior, knowledge of public values, social rules single ands public orientation. The study recommended by necessity of focus on ethics rules in production, pricing, distribution, promotion, general benefits, repositioning for many values as validity, justice, and fair.

Songa Gensler et al. (2013) "managing brands in the social media environment". The study knowledge about the dynamic environment by many aspects as culture, and social-ethics, it explore how deal with social media laws and regulations, ubiquitous and often real-time interaction enabled by social media significantly changes the land scape for brand management but the findings focus on new dynamic networks for customers and firms need to pay attention to consumer-generated brand stories to ensure brand success. Samir abu zaid (2012) "Islamic marketing". The study aimed to define the gap of data mix, knowledge of sales person, and how develop the skills to deal with customers, the study explains that Islamic marketing building on ethics and social values and it recommended focusing at many aspects as: suppose managers, sales person and motivate them to commitment on Islam values, ethics, responsibilities, religion rules. AL Kateeb Kalid (2008) "The managerial ethics effects 
on accounting responsibilities" Jordan. The study aimed to knowledge abate globule challenges, ethics and accounting, controlling, performance, evaluation the effects of ethics. The study explains that responsibility is a tool of controlling, organization ethics is a behavior, career ethic, individual behavior. The study recommended by: commitment the divisions in firms, applied ethic criteria, training course. Gatangli sammer (2004) "Islamic Jurisprudence" Lebanon. The study aimed to knowledge the basic jurisprudence in Islam religion as ethic, responsibility, accounting and explain how the Islam focus on ethics fundamentals, accounting and commitment it recommended to audit, check, validity, integrity, equity, justice.

\section{Conceptual Model}

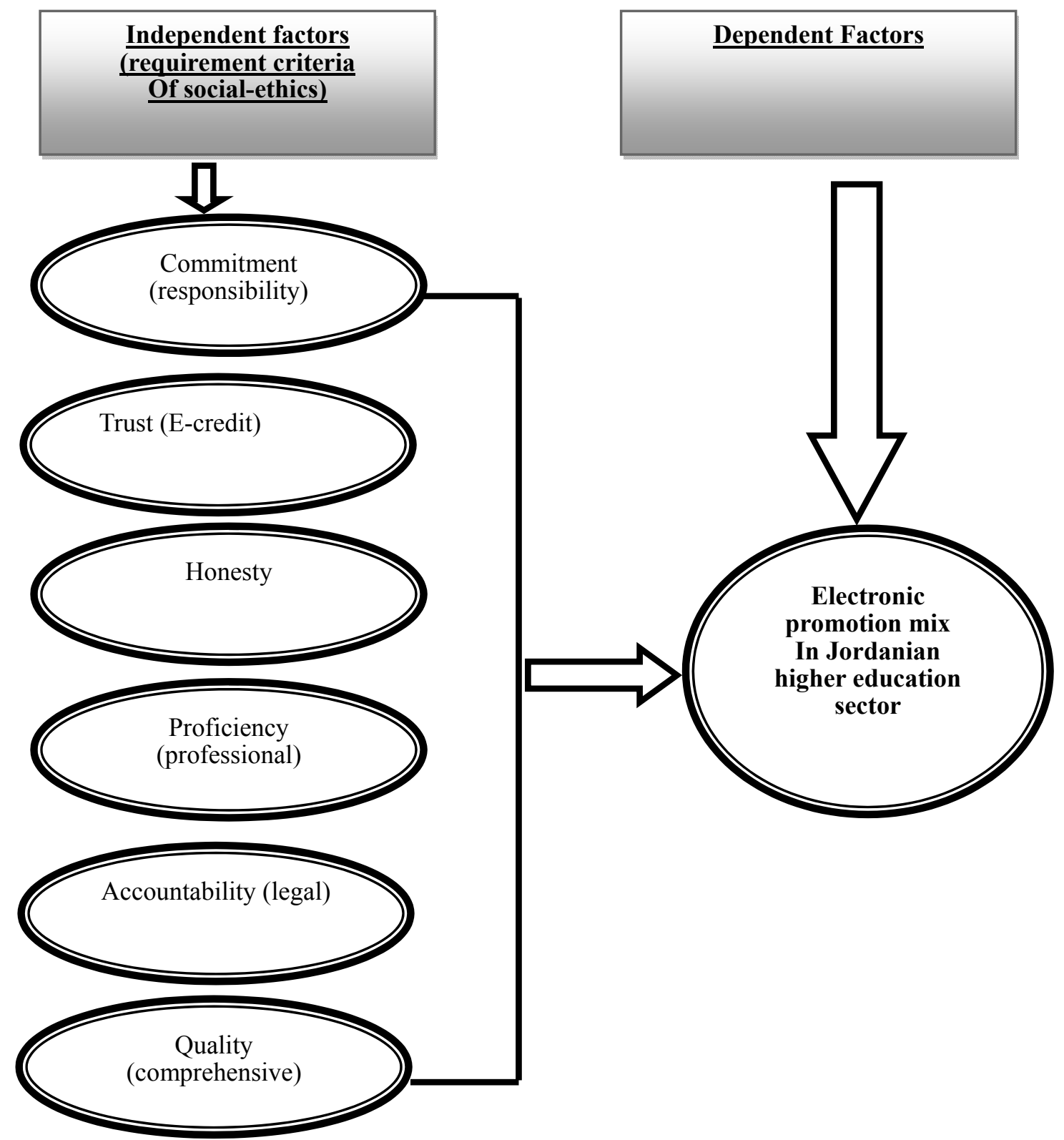

Figure 1. The model of study

\section{Research Hypothesis}

The study hypotheses have been formulated based on the problem and variables of the stud. However, the main hypothesis was developed based on the study of (Vermin \& Gross, 2002).

\section{(a) - The main hypothesis:}

There is statistically significant relationship at $(\infty \leq 0.05)$ between the ethics, social criteria dimensions 
(commitment, trust, honesty, proficiency, accountability, quality) and electronic promotion activities in Jordanian Higher Education sector.

\section{(b) - The sub hypotheses:}

- There is statistically significant relationship at $(\infty \leq 0.05)$ between the (criteria of commitment) and electronic promotion activities in Jordanian Higher Education.

- There is statistically significant relationship at $(\infty \leq 0.05)$ between the (criteria of trust) and electronic promotion activities in Jordanian Higher Education.

- There is statistically significant relationship at $(\infty \leq 0.05)$ between the (honesty) and electronic promotion activities in Jordanian Higher Education.

- There is statistically significant relationship at $(\infty \leq 0.05)$ between the (proficiency) and electronic promotion activities in Jordanian Higher Education.

- There is statistically significant relationship at $(\infty \leq 0.05)$ between the (accountability) and electronic promotion activities in Jordanian Higher Education.

- There is statistically significant relationship at $(\infty \leq 0.05)$ between the (qualities) and electronic promotion activities in Jordanian Higher Education.

\section{Methodology, Variables and Sample of the Study}

The researcher adopted the descriptive analysis approach and the correlations, regressions to examine the effect of social, ethics criteria on electronic promotion activities in higher education in Jordan. The reliability and validity tests are used based on Cronbach's Alpha and the mean tests as show in Table 1. However, the researcher studied all managers in universities (100) questionnaire by survey study whose response for study from (100) managers and received it which it mean $100 \%$ from population study, I applied survey study on all managers, we tested our hypothesis by keeping main focus on the electronic promotion and social-ethics criteria and how for modifying between their effects. Data were collected in two ways: first was primary data: by questionnaire and secondary data: adoption of reference, periodicals, website, case study, and questionnaire were sent to answer of professors and professional for arbitration.

Table 1 . Reliability of scales

\begin{tabular}{lll}
\hline & N. Items & Alpha (a) \\
\hline COMMITMENT & 5 & 0.77 \\
TRUST & 5 & 0.75 \\
HONESTY & 5 & 0.87 \\
PROFICIENCY & 5 & 0.87 \\
ACCOUNTABILITY & 5 & 0.89 \\
QUALITY & 5 & 0.85 \\
\hline
\end{tabular}

\subsection{The Study Variables}

The ethics fundamentals have argued in many studies for examples, the study of (Pride \& Ferrell, 2003) argued that, it necessary to obligate the organizations by many ethics as basics rules (Legitimacy, Responsibility, Sincerity and affection, Fulfillment, Neutrality, Ethics kinds, Public ethics, Provisional ethics, Organizational ethics, Moral ethics and Morality ethics). However, the Social-Ethics responsibility in general the marketing activities in higher Jordanian private sector considered the first indictor of its success, the philosophy of private sector is based on many elements as (marketing, customers, responsibilities, ethics, social, goals) (GOD said to prophet Mohammed for telling Muslims in sort altoba, there should be every one doing but the GOD sea you, ayah 105). There for the ethic and social you should have an orientation reward its responsibilities in private sector and maximize its benefits, depend on updating and developing policies in ethic and social dimensions (Zachary, 2013).

Commitment: it's the major principle of Islamic ethics is hitch means the individual agree and accept the judge of all population to applying it satisfy and keep on his responsibility, it helps employee to be more active in business sector (Chen, 2008).

Trust: it is the degree of validity in work, credit between marketing operation dimensions, and should be clear, transpierce, cured, Idol, and act accurately, finally repositioning in correct way (Chen, 2008). 
Honesty: it is the other face of commitment and part of Islam ethic system and its values, it considers as indictor for ethic behavior in business sector, reflect the commitment degree in applying production standers, service after (Hassan et al., 2005).

Proficiency: it means the skills, experience, which necessary for employee in firms for enhancing the performance, increase productivity, improved, adapting with new technology, focus on quality, customer changes requirements, care with technology degree, commitment of interposal standers, customer perceptions helps to satisfy the customers (Gea ed ibrahim, 2017).

Accountability: it means the fundamental of ethics to admits by jobs and acts professionally there was behave under God it salt, society, control, which mean individual responsibility there are many goals for accounting as efficiency, effectively, motivation applied administration function (Alkhateeb, 2008).

Quality: it's a basic fundamentals depends on self control to enhance the customer satisfaction, loyalty, maximize sale and profit, thus the quality indicate to ethic part (agarwal, 2010), it's a required criteria for e-business organization and effects on achieving competitive advantages additionally it reflect a unique image about firm production (Gea ed ibrahim, 2017).

\section{Jordanian higher education sector:}

Jordanian government support educational trend, literacy in Jordan about $96 \%$, there are many factors encourage that as job opportunities internally and regionally (article, alrai.com, 2018).

In 1958 the higher education started by 1 university at public sector but now that is 10 universities, on the other hand the private higher education start on 1990, it has 24 universities now, on 1980 establish ministry for higher education, in 1982 issue higher education law, on 2017-2018, 134779 under graduate students, 18810 graduate students, the citizens in Jordan consider the education as value and wealth (www.mohe.gov.jo).

Electronic promotion mix: The services become necessary for customers because it satisfy more needs, wants, preferences and inter all aspects of economy, then effect on marketing operation, over that its very essential to the organization for achieving their goals (Lovelock \& Writz, 2004), but electronic promotion recently becomes better than specialty with social media (Singh, 2012).

The marketing activities need many processes of progressing improvement of harmony with the forces of external, internal dynamic or turbulent environment interacting by rapid changes in needs and wants (Zyadat, 2012).

The Jordan higher education ought to develop the performance and increase the abilities of private firms to achieve their goals and detailed objective (Algaliby \& Alamery, 2013). However, the private education in Jordan passed many stages to progress the quality of education by planning focusing, various products, marketing researches, buying behavior analysis, opportunity analysis, strength point, planning marketing miss process develop detail plans (Abdalhady, 2014). Also, the education market in Jordan have public sector and private sector which means that high degree of competition, regulations, laws. The performance of private higher education in Jordan has many indictors as earnings, the market share, customer's satisfaction, sales volume (Islamic Arab center, 2012).

\subsection{Population of the Study, Sample}

The study population consists of all managers at private education factor in Jordan by 100 managers, given the difficulty of the inclusion of all managers in sector, we choose 88 managers as sample of the study randomly, and distributed an sample 88 questionnaires retrieved questionnaire is 88 as shown in Table 2. Furthermore, the SPSS soft-ware is used in this study to examine the effect of the social-ethics required criteria on electronic promotion activities for higher education in Jordan.

Table 2. Descriptive statistics

\begin{tabular}{llllll}
\hline & $\mathrm{N}$ & Minimum & Maximum & Mean & Std. Deviation \\
\hline COM & 88 & 3.44 & 23.33 & 12.9291 & 3.81040 \\
TRU & 88 & 3.75 & 24.44 & 13.8430 & 4.47073 \\
HON & 88 & 3.78 & 25.00 & 14.5614 & 4.21659 \\
PRO & 88 & 7.08 & 24.44 & 15.6342 & 3.99117 \\
ACC & 88 & 5.37 & 25.00 & 15.4292 & 4.25656 \\
QUA & 88 & 4.16 & 25.00 & 15.6756 & 4.62025 \\
Valid N (list wise) & 88 & & & & \\
\hline
\end{tabular}




\section{Conclusion and Results Analysis}

The purpose of this paper is to investigate the effect of the social-ethics required criteria on electronic promotion activities for higher education in Jordan. After researcher had finished from collecting data on the study variables, some indicators in (SPSS) were used so as processing data that have been obtained through the field study the (reliability of scale, descriptive statistics, correlations, co linearity statistics, nova, coefficients) tests are used. Generally, the main findings of this study are:

A: Extent of ethics, social responsibility application is low.

B: There is variance between these variable applications.

C: It has gaps between electronic promotion activities and their applications on higher education service.

However, to verify the internal content of questionnaire it was display in its initial picture to 5 arbitrators specialized in the field of marketing and management in the Jordanian universities and the illustrates the internal consistency of the items of questionnaire related to the study variables are showed in Table 1 using cranach's alpha coefficient test. In Table 1 shown the internal consistency 0.84 which mean that Avery good degree of coverage and suitable to check and explain the coefficient, but in Table 2 the arithmetic means, standard deviations and ordering of the items of ethic-social responsibility variables become suitable on good degree without proficiency, in whole the model consist of many variables related electronic promotion. Also, In Table 2 the standard deviation come between 3-4 which mean that all variables have effects on electronic promotion and help to maximize profit, customers, sales.

In Table 3 correlation coefficient which measure strength of variables, it becomes accountability, on very good degree (0.87) and total results are positive, but in Table 4 the independent variables can measure and forecasting its effects on dependent variables strongly, but in Table 5 the model of study is suitable, strong, achieve the study goals, because (R) bigger than (R2) which mean the model is effective.

Table 3. Correlations

\begin{tabular}{llllllll}
\hline & & RS & LS & RP & LP & EVS & PP \\
\hline COM & Pearson Correlation & 1 & $.612(* *)$ & $.639(* *)$ & $.660(* *)$ & $.717(* *)$ & $.609(* *)$ \\
& Sig. (2-tailed) & & .000 & .000 & .000 & .000 & .000 \\
& N & 88 & 88 & 88 & 88 & 88 & 88 \\
TRU & Pearson Correlation & $.612(* *)$ & 1 & $.597(* *)$ & $.676(* *)$ & $.591(* *)$ & $.650(* *)$ \\
& Sig. (2-tailed) & .000 & & .000 & .000 & .000 & .000 \\
& N & 88 & 88 & 88 & 88 & 88 & 88 \\
HON & Pearson Correlation & $.639(* *)$ & $.597(* *)$ & 1 & $.678(* *)$ & $.807(* *)$ & $.517(* *)$ \\
& Sig. (2-tailed) & .000 & .000 & & .000 & .000 & .000 \\
& N & 88 & 88 & 88 & 88 & 88 & 88 \\
PRO & Pearson Correlation & $.660(* *)$ & $.676(* *)$ & $.678(* *)$ & 1 & $.724(* *)$ & $.708(* *)$ \\
& Sig. (2-tailed) & .000 & .000 & .000 & & .000 & .000 \\
& N & 88 & 88 & 88 & 88 & 88 & 88 \\
ACC & Pearson Correlation & $.717(* *)$ & $.591(* *)$ & $.807(* *)$ & $.724(* *)$ & 1 & $.608(* *)$ \\
& Sig. (2-tailed) & .000 & .000 & .000 & .000 & & .000 \\
& N & 88 & 88 & 88 & 88 & 88 & 88 \\
QUA & Pearson Correlation & $.609(* *)$ & $.650(* *)$ & $.517(* *)$ & $.708(* *)$ & $.608(* *)$ & 1 \\
& Sig. (2-tailed) & .000 & .000 & .000 & .000 & .000 & 88 \\
& $\mathrm{~N}$ & 88 & 88 & 88 & 88 & 88 & 8 \\
\hline
\end{tabular}

Note. $* *$ Correlation is significant at the 0.01 level (2-tailed).

* Correlation is significant at the 0.05 level (2-tailed).

Table 4. Co linearity statistics

\begin{tabular}{|c|c|c|}
\hline \multirow[t]{2}{*}{ Model } & \multicolumn{2}{|c|}{ Co linearity Statistics } \\
\hline & Tolerance & VIF \\
\hline COM & .632 & 1.582 \\
\hline TRU & .735 & 1.360 \\
\hline HON & .675 & 1.482 \\
\hline PRO & .705 & 1.418 \\
\hline $\mathrm{ACC}$ & .644 & 1.552 \\
\hline QUA & .634 & 1.578 \\
\hline
\end{tabular}


Table 5. Model summary

\begin{tabular}{llllll}
\cline { 2 - 5 } & Model & $\mathrm{R}$ & $\mathrm{R}$ Square & Adjusted R Square & Std. Error of the Estimate \\
\hline Note. a Predictors: (Constant TRU, HON, PRO, ACC, QUA). & & .773 & .62444 \\
\hline
\end{tabular}

In Table 6, mean square becomes 166.408 but $\mathrm{f}$ becomes 426.775 which mean (.000) it significent, but in Table 7 , test (B) becomes significant for all variables with its important and the high degree is .480.

Table 6. ANOVA (b)

\begin{tabular}{lllllll}
\hline Model & & Sum of Squares & df & Mean Square & F & Sig. \\
\hline 1 & Regression & 1331.267 & 8 & 166.408 & 426.775 & $.000(\mathrm{a})$ \\
& Residual & 33.533 & 86 & .390 & & \\
& Total & 1364.800 & 94 & & & \\
\hline
\end{tabular}

Note. a Predictors: (Constant), TRU, HON, PRO, ACC, QUA.

b Dependent Variable: PP.

Table 7. Coefficients (a)

\begin{tabular}{lllllll}
\hline \multirow{2}{*}{ Model } & & \multicolumn{2}{l}{ Unstandardized Coefficients } & Standardized Coefficients & $\mathrm{t}$ & Sig. \\
\cline { 3 - 7 } & & $\mathrm{B}$ & Std. Error & Beta & $\mathrm{B}$ & Std. Error \\
\hline 1 & (Constant) & -.412 & .313 & & -1.316 & .192 \\
& TRU & .414 & .062 & .486 & 6.626 & .000 \\
& HON & .416 & .061 & .461 & 6.832 & .000 \\
& PRO & .030 & .029 & .031 & 1.033 & .005 \\
& ACC & .059 & .030 & .066 & 1.977 & .051 \\
& QUA & .016 & .022 & .019 & .707 & .002 \\
\hline
\end{tabular}

Note. a Dependent Variable: PP.

The analysis obtained the answers of the study questions and testing its hypotheses. Furthermore, all the statistical values are greater than the level of significance $(\infty \leq 0.05)$, the results presented in Table 4 showed a high consistency of multi-co linearity between (the dimensions of ethic-social responsibility) what confirms the values of (VIF) and testing the study hypotheses, the model is suitable and has high level of consistency, the study instrument is good and cover many aspects of ethic-social.

Also, the results of this study show that there is high degree of ethic-social effects on Jordanian private education sector because the population study is awaernce, civilized, focus on higher education for many reasons as improve income, motivations, and legal aspects require the sector to face it responsibilities.

The variables (honesty, accountability, quality) are becomes too affecting on marketing activities and promoting for higher education in Jordan, it helps to satisfy customers and enhance the customer loyalty degree. The variables (trust, commitment, proficiency) are becomes affecting on marketing activities, very necessary to improve education sector, for keeping the customers in touch with Jordanian private sector and focus on institutions goals to achieve competitive advantages.

\section{Recommendations}

The study after results, analysis reaches for good recommendations as the following:

1) It should be study other variables which not cover by this study as word of mouth, religion attitudes.

2) Focus on organizational behavior in higher Jordanian private sector.

3) Reactive the role of (accounting responsibility, commitment), because it's very necessary for modern marketing.

4) Reorganize the education operation to exploit the sector performance.

5) Reinforcment the customer's level of loyalty.

6) Focus on Islamic ethics.

7) Balancing the level of focus on ethic-social responsibilities.

8) Improve the employee's skills in higher Jordanian private sector. 
9) Improve the education marketing mix in higher Jordanian private sector.

10) Support the institutions in higher Jordanian private sector which committed by ethics responsibilities laws and regulations.

11) Diversifying the education services in higher Jordanian private sector.

12) Exploiting the competitive abilities in higher Jordanian private sector.

13) Emphasize on commitment by criteria of ethics-social at E-promotion campaign.

\section{References}

Abdalhady, I. (2014). Business ethics and organization responsibility. Eygept, banha university.

Abo dalbouh, M. A. (2017). Marketing tourism (1st ed.). Jordan, Amman, alamsamma.

Agarwal, N., \& Yiliyasi, Y. (2010). Information quality challenges in social media "international conference on information quality (iciq, 2010). Little rockansas.

Al-Dmour, H. (2009). Services marketing (5th ed.). Jordan, Amman, dar weal.

Alex garrett, K. S., \& Cara, W. (2017). Digital channels for building collaborative consumption communities. Journal of Resaerch in Interactive Marketing, 11(2). https://doi.org/10.1108/JRIM-08-2016-0086

Algaliby, S., \& Alamery, T. (2013). The social responsibility and business ethics (1st ed.). Jordan, amman, dar jeerer.

Ali, J. (2012). Quantitative approach in management (1st ed.). Jordan, Amman, 1th, daralthagafa.

Alktaeib, K. (2008). Business ethics and their effects on accounting. Jordan, amman, petra university.

AL SMAK, M. (2014). The Ethic Regulation for Media "Syria". Unpuplisher Research.

Amine, A., \& Izaldeen, S. (2009). Promotion by internet and its effects on cost. Master thesis, Sudan, sudan technology university.

Article. (2018). Retrieved from http://www. alrai.com

Cayla, J., \& Eric, A. (2008). A Cultural Approach to Branding in the Global Marketplace. Journal of International Marketing, 16(4), 88-114. https://doi.org/10.1509/jimk.16.4.86

Center of Islamic Arab studies. (2012). Characteristics of sales men in Islamic banks, emirate, banking. Islamic Journal.

Chen, Y. B., \& Xie, J. H. (2008). Online Customer Review: Word of Mouth at a New Element of Marketing Communication Mix. Management Science, 54(3). https://doi.org/10.1287/mnsc. 1070.0810

Fatema, H., Caroline, A. H., Michael, J. V., \& Michael, C. (2015). E-Marketing Orientation and Social Media Implementation in B2b Marketing. European Business Review, 27(6), 638-655. https://doi.org/10.1108/EBR-03-2015-0026

Gatangli, S. (2004). Islamic Jurisprudence. Lebanon, unpublished research.

Gea ed, I. (2017). Electronic Promotion and customer behavior. Doctorate dissertation, Algeria.

Hassan et al. (2005). Managerial accounting in business environment. Jordan, Amman, daraledham.

Hennig-Thurau, T., Kevin, G., Gianfranco, W., \& Dwayne, G. (2004). Electronic Word of Mouth via Consumer Opinion Platforms, what motivates consumers to articulate themselves on the internet. Journal of Interactive Marketing, 18(1), 38-52. https://doi.org/10.1002/dir.10073

Higher Education Ministry in Jordan. (2013). Report. Jordan, amman.

Homas, D. (2006). Case studies in business ethics. NewJersy, USA: Prentice-hall, Inc.

Joung, P., \& Demetris, V. (2006). Building corporate branding through internal marketing. Journal of Product and Brand Management, 15(1). https://doi.org/10.1108/10610420610650864

Kenneth, C., \& Jane, P. (2012). Management information system (11th ed.). Retrieved from http://www.prentichall.com

Kittler, F. P. (2011). Marketing management (12th ed.). NewYourk, USA: MacGrawHill.

Kuksov, M., Ron, S., \& Kangkang, W. (2013). Advertising Consumers Communications. Marketing Science, 32(2), 294-309. https://doi.org/10.1287/mksc.1120.0753 
Lovelock, C., \& Writs. (2004). Service marketing (4th ed.). UK: Pearson.

Mulhem, F. (2009). Integrated Marketing Communications: From Media Channels to Digital Connectivity. Journal of Marketing Communications, 15(3), 85-101. https://doi.org/10.1080/13527260902757506

Pride, W., \& Ferrell. (2003). Marketing, concepts and strategies (3rd ed.). New Your, USA: Houghton, Mifflin.

Rowley, J. (2001). Remodeling marketing communications. in an internet environment. Internet Research: Electronic Networking Applications and Policy, 11(3). https://doi.org/10.1108/10662240110397017

Samir, A. Z. (2012). Islamic Marketing. Unpuplisher Research, Isra University, Amman, Jordan.

Samreen, L., \& Maria, S. (2017). Impact of E-Marketing on Consumer Behviour, Acase of Karachi, Pakstan. Journal of Business and Management, 19(1). 90-101. https://doi.org/10.9790/487X-19010590101

Shamy, K., Mayany, Y., \& Zillur, R. (2018). Impact of Social media and customers-Centric Technology on Performance out Comes: The Medicating role of Social CRM Capabilities. International Journal of E-Marketing and Retailing, 9(2). https://doi.org/10.1504/IJEMR.2018.10010272

Singh, S., \& Stephan, S. (2012). Prand Performance in Social Media. Journal of Interactive Marketing, 26(4), 97-189. https://doi.org/10.1016/j.intmar.2012.04.001

Smita, S., \& Asad, R. (2017). Impact of social relationships on electronic of mouth in social net worjing sites: a study of Indian social networkusrs. International Journal of Electronic Marketing and Retailing, 8(2). https://doi.org/10.1504/IJEMR.2017.10006395

Songa, G., Franziska, V., Liu-thompkins, Y. P., \& Caroline, W. (2013). Manging brands in the social media environment. Journal of Interactive Marketing, 27, 242-256. https://doi.org/10.1016/j.intmar.2013.09.004

Teas, R. K., \& Agarwal, S. (2000). The effects of extrinsic product cues on consumers perceptions of quality. Journal of the Academy of Marketing Science, 280-292.

Verma, H., \& Gross. (2002). Introduction to quantitative methods (2nd ed.). New Yourk: Jhon wiley. Retrieved from http://www.mohe.gov.jo

Zachary, R., David, T., Kim, C., \& Sarah, T. (2013). The Social Behaviors of Your B2B Customers. Retrieved from $\mathrm{http} / \mathrm{www}$.forrester.com

Zeithmal, V. A., \& Bitner, M. (2003). Services marketing. New York, USA: MacGraw Hill.

Zyadat, M., \& Alawamra, M. (2012). Marketing strategies integrated perspective (1st ed.). Amman, Jordan: dar-alhammed.

\section{Copyrights}

Copyright for this article is retained by the author, with first publication rights granted to the journal.

This is an open-access article distributed under the terms and conditions of the Creative Commons Attribution license (http://creativecommons.org/licenses/by/4.0/). 